\title{
I Love to Learn, but I Hate to be Taught
}

\author{
Perry Gao \\ Correspondence: Perry Gao, College of Education, University of Oregon, Eugene, OR 97403-1215, USA.
}

Received: April 23, 2014

doi:10.11114/jets.v2i3.392

\author{
Accepted: May 16, 2014 \\ Online Published: June 10, 2014 \\ URL: http://dx.doi.org/10.11114/jets.v2i3.392
}

\begin{abstract}
Children naturally love to learn, but might not like to be taught in certain ways. Teachers' improper ways of teaching might make a child shut down his or her willingness to learn, which is called not-learning. Not-learning does not refer to an incapability to learn, but is rather a choice a child intentionally or unintentionally makes to resist learning. This paper explains how not-learning is a major obstacle for children's development and argues that teachers should be responsible for avoiding not-learning. This paper also discusses how teachers can use culturally relevant teaching to avert not-learning and help children have effective learning experience.
\end{abstract}

Keywords: education, not-learning, cognitive development, intellectual development, culturally relevant teaching, effective learning

\section{Introduction}

It is not rare to see a child shut down his or her willingness to learn. Herbert Kohl (1994) labeled this phenomenon as not-learning, which is not a failure of learning, but is a choice a child intentionally or unintentionally makes to resist learning. Sadly, when this happens, we often hear teachers say, "I cannot teach that student because he or she is not willing to learn at all." This saying is actually an excuse implying that teachers are not responsible for the not-learning of a child. However, the famous British politician, Winston Churchill, straightforwardly refuted this idea by saying, "I'm always ready to learn, although I do not always like being taught." Children originally love learning; their first intention is not to shut down learning; nevertheless, the teacher's approach to teaching can be the factor that makes students feel uncomfortable enough to let them shut down learning (Gao, 2014; Holt, 1982). Therefore, teachers should recognize that children always love learning, but they might just hate to be taught, or hate to be taught in ways that make them feel offended or alienated. This paper theoretically illustrates that unequal social powers and cultural alienation are able to cause negative impact to cognitive and intellectual development by causing not-learning. This paper will also talk about how teachers can use culturally relevant teaching to build a just sociocultural context to avoid not-learning and help children learn effectively.

\section{Not-Learning - A Crisis in Development}

Vygotsky (1980) believed learning is the sole driver of development. Hence, learning is what makes a child become a more intelligent person and what pushes a child's cognitive development forward. In addition, Vygotsky (1980) also believed learning from more knowledgeable others creates the zone of proximal development. People who believe children should be responsible for their own learning always think children can learn on his or her own, regardless of whether the children like the teacher; that as long as children are exposed to knowledge, they can learn and develop. In reality, this is not the case. According to Vygotsky's theory, we know a child is only able to learn very superficial things on his or her own, and he or she alone can only accomplish very basic development, far less than his or her potential developmental level. Therefore, a child has to learn from others, from teachers' instructional scaffolding in most cases, in order to have an advanced development (Vygotsky, 1980; Wood, Bruner, \& Ross, 1976). Recognizing this concept is important, responsible teachers have to realize they are essential to children's learning. Acknowledging this means teachers cannot simply give up and leave the child to his or her own path, that they are obligated to find a way to scaffold children's learning. If teachers do the right work, they will have the irreplaceable advantage to help children have deep and comprehensive learning. If teachers do not do well, they will make children lose the opportunity to have advanced development.

Kohl (1994) asserted that if teachers give negative emotions to children, it will produce negative impacts on children's cognitive and intellectual development. Once children feel they have been treated unfairly by teachers they will build up a psychological filter as an emotional block to shut down their willingness to learn (Kohl, 1994; Illeris, 2009; Delpite, 
2006; Ladson-Billings, 2009). Children are always in a situation in which they lack power, which means that when they perceive unfairness being done to them, they lack means of resistance. For example, when a child has a conflict with a teacher, the child is always vulnerable because teachers are authority figures. Therefore, the only way the child can do something is to stop learning from that teacher. Sometimes this can be a choice a child makes, sometimes this can be a child's instinctive reaction to protect their ego from anxiety, which is related to Freud's (2011) defense mechanisms (Illeris, 2009). Emotions can impact our learning, and emotions are usually beyond what we can control consciously, especially for emotionally and cognitively underdeveloped children (Kohl, 1994; Illeris, 2009; Delpite, 2006; Ladson-Billings, 2009). Hence, teachers should not blame children for shutting down their willingness to learn because it can be an unintentional choice children make directly caused by what the teacher does. I believe not-learning is a crisis because it emotionally hurts a child, and it stops a child's development from learning from more knowledgeable others. Furthermore, it also often takes place very quietly, and it is not easy for people to notice. Although it is not a failure of learning, it definitely can lead to the educational failure of a child. Teachers have to develop a consciousness to recognize how not-learning occurs and what causes it.

\section{Causes of Not-Learning}

When children feel offended or insulted, not-learning is likely to take place, which is often caused by unequal social powers and cultural alienation. When a child finds out there is a conflict between his or her subordinate culture and the dominant culture, and the child feels uncomfortable with that, he or she might build up a psychological filter and go into not-learning (Kohl, 1994; Delpite, 2006; Cummins, 2000).

Unequal social powers are inherent in the authority bestowed upon teachers. Delpite (2006) and Cummins (2000) studied how this often happens in language teaching. Many children do not speak Standard English at home, using colloquial home languages instead. However, schools always aim at teaching students Standard English. This difference is not in itself enough of a conflict to make children choose not-learning unless teachers make children feel disrespected (Delpite, 2006; Cummins, 2000). For example, a teacher once said to the students that the home language they were speaking was wrong, that it was not a right way to speak. This offensive statement made students feel their family's dignity had been offended and insulted, and consequently some students went into not-learning and refused to learn from that teacher (Delpite, 2006; Cummins, 2000).

Another cause is cultural alienation. When a child faces a cultural conflict in school, he or she might become aggravated and go into not-learning (Kohl, 1994; Illeris, 2009). I assert that this happens because teachers fail to use a child's current knowledge or skillset to foster learning. Vygotsky (1980) thought teachers should use what a child already knows as a bridge to construct new knowledge, and that therefore teachers' teaching should be just within a child's zone of proximal development.

The last cause is not very obvious, but it is important for teachers to realize. Teachers' low expectations of students can result in students' poor performance (Delpite, 2006; Ladson-Billings, 2009). Children can perceive whether a teacher is seeking excellence from them. Low expectations imply that the teachers believe the students are not capable learners, which is related to unequal social powers. This negative psychological suggestion can cause children to lose confidence and can drain their passion for learning.

\section{Establishing a Just Sociocultural Context}

We have already discussed that unequal social powers, cultural alienation and low expectations are able to make children intentionally or unintentionally build up a psychological filter as a mental block to shut down their willingness to learn and go into not-learning. Not-learning stops children's learning from others, and that will result in reduced childhood intellectual and cognitive development.

Rogoff (2003) and Vygotsky (1980) both thought a child's learning must be understood in its sociocultural context. In other words, the sociocultural environment impacts a child's development. Children are a part of the community life that they observe and participate in; children are learning and developing through sociocultural interactions (Rogoff, 2003; Vygotsky, 1980). Teachers have the most direct access to provide scaffolding in the classroom, and they should be the main resource children learn from. In reality, the teacher is one of the most important available resources that children can learn from in order to have the zone of proximal development. Teachers should carefully examine their teaching and try to avoid causing children who originally love learning to learn to hate being taught by us because of teachers' recklessness and disrespect. We should always remember children love learning, but they might hate being taught in certain ways. We should always evaluate and adapt our pedagogy by using culturally relevant teaching to build up a just sociocultural context to make children feel respected and comfortable.

\section{Using Culturally Relevant Teaching to Fulfill Effective Learning}

The teacher's role is very significant because they provide scaffolding to help children construct new knowledge and 
skills which children cannot accomplish on their own. Hence, teachers need to recognize they are playing an important part in children's development. Teachers should use culturally relevant teaching so as to recognize the different cultural and personal backgrounds and the uniqueness of a child, to use what children are familiar with as an entry point to teach respectfully, and should also try to provide frequent positive feedback (Delpite, 2006; Rogoff, 2003; Ladson-Billings, 2009; Gay, 2002; Moll, 1992; Perez, 2004; Vygotsky, 1980). This culturally relevant teaching model is an effective way to help children learn and have proximal development.

\subsection{To Recognize the Cultural and Individual Differences}

Professor Melvin Konner once said that, "In order to be treated fairly and equally, children have to be treated differently." Awareness of differences among cultures and students allows teachers to develop a respectful attitude. Not-learning happens a lot in language teaching. As mentioned above, once students feel their home culture, language, and family's dignity have been offended, they are very likely to go into not-learning and refuse to learn from that teacher (Delpite, 2006). Teachers should realize that home languages are cultures that should be respected, not speech disorders. Hence, a successful teacher should recognize cultural differences and respect them by using polite approaches to teaching. For example, instead of saying a home language is wrong, teachers should say, "The home language is good, but we need to practice Standard English at school." Teachers can honestly and sincerely tell students that "Standard English is what can help you have access to power, and I would like you to be successful and have that access." Children will perceive teachers' sincerity and good intentions; also, they will be willing to learn from a teacher who is respectful and tactful.

I also emphasize the significance of realizing individual differences, because when people focus too much on the differences among children's cultural backgrounds, they can easily develop a stereotype (Rogoff, 2003). For example, Ladson-Billings's (2009) case study showed that there were teachers who believed African-American students were good at sports but not good at academic learning, so they lowered their expectations for those students. As a result, the students did not put much effort into studying. Therefore, Rogoff (2003) reminded us that instead of trying to find similarity, we should focus more on understanding every individual's differences. We should see personal differences in order to adapt our teaching to fit every child. The general story is not necessarily wrong, but it is not accurate enough for individuals (Adichie, 2009).

\subsection{Culturally Relevant Teaching - A Bridge Connecting to New Knowledge}

When a child faces to a serious cultural conflict in school, he or she might feel aggrieved and go into not-learning. Therefore, after recognizing children's cultural backgrounds, Ladson-Billings (2009) and Gay (2002) suggested that teachers should use what children are familiar with as an entry point to teach them new things. Teachers should aim for relevance in children's current culture as a bridge to make connections to the new knowledge that teachers can offer (Ladson-Billings, 2009; Gay, 2002). Vygotsky (1980) and Perez (2004) thought people should use their old knowledge and skillset to construct new knowledge; and teachers should teach in children's zone of proximal development, over simple knowledge cannot contribute to children's development, proper challenge pushes children to develop. Over difficult knowledge or excessive challenge overwhelm children, and might cause not-learning. In language education, children tend to treat language study as an isolated discipline, do not see meaning and relevance in learning, and do not view language is a useful communicational tool (Valdés, 2001). Ladson-Billings (2009), and Moll (1992) suggested that teachers should use what children were familiar with in their own culture and language context to show children the similarity and differences between English and their mother language. If this is done, then the teacher can efficiently teach Standard English to children.

In addition, making connections between students own cultural background might show students that teachers care about and respect their home culture, as well as show students what teachers teach is meaningful and relevant to their lives. And thus, it might make teachers easy to build up a trusting relationship with students.

\subsection{Don't Forget Praise}

Low expectations often result in students' poor performance (Delpite, 2006; Ladson-Billings, 2009). Bronson and Merryman (2009) pointed out that, high expectations along with praise and encouragement lead to good outcomes, as the positive feedback reinforces high expectations and the pursuit of excellence. Negative feedback and punishment, on the other hand, cause children to develop aversive and antisocial behaviors (Biglan, 2003; Laub \& Sampson, 1995). Ladson-Billings (2009) further pointed out that low expectations with discouragement imply teachers do not believe that students are capable learners. This negative psychological suggestion results in children losing their confidence, reducing their self-esteem, and diminishing their passion for learning. Therefore, teachers should give children positive feedback, especially specific feedback, which will make children believe they are important and their personal characters and culture are being respected. 


\section{Final Words}

I hope this paper helps teachers realize that students do have an innate love of learning. Their natural curiosity pushes them to be eager for new knowledge. Teachers' moral obligation requires them to be the most significant support and resource to help children develop through learning. I don't believe that any teacher wants to eliminate students' passion to learn, however teachers' unintentional improper approaches to education might make children shut down their willingness to learn. Children are emotionally vulnerable, so responsible teachers are supposed to develop a sensitive awareness to how their teaching affects children, and especially whether it makes them feel uncomfortable. Teachers should also establish a critical consciousness oriented towards establishing a just sociocultural context to avoid not-learning, a goal which can be furthered by using culturally relevant teaching to help children fulfill effective learning. However, the challenge is that every child is different and unique, and therefore there is no certain approach to teaching that is appropriate for every child. In order to benefit all children, teachers should use personalized education instead of standardized education (Gao, 2014).

\section{References}

Adichie, C. (2009). The danger of a single story. TED Ideas worth spreading.

Biglan, A. (2003). Selection by consequences: One unifying principle for a transdisciplinary science of prevention. Prevention Science, 4(4), 213-232. http://dx.doi.org/10.1023/A:1026064014562

Bronson, P., \& Merryman, A. (2009). NurtureShock: New thinking about children. Hachette Digital, Inc..

Cummins, J. (2000). Language, power, and pedagogy: Bilingual children in the crossfire (Vol. 23). Multilingual Matters.

Delpit, L. D. (2006). Other people's children: Cultural conflict in the classroom. The New Press.

Freud, A. (2011). The ego and the mechanisms of defence. Karnac Books.

Gao, P. (2014). Using Personalized Education to Take the Place of Standardized Education. Journal of Education and Training Studies, 2(2), 44-47. http://dx.doi.org/10.11114/jets.v2i2.269.

Gay, G. (2002). Culturally responsive teaching in special education for ethnically diverse students: Setting the stage. International Journal of Qualitative Studies in Education, 15(6), 613-629. http://dx.doi.org/10.1080/0951839022000014349.

Holt, J. C. (1982). How children fail. Da Capo Press.

Illeris, K. (2009). A comprehensive understanding of human learning. In K. Illeris (Ed.), Contemporary theories of learning: Learning theorists ... in their own words (pp. 7-20). London: Routledge.

Kohl, H. (1994). "I Won't Learn from You" and Other Thoughts on Creative Maladjustment. The New Press.

Ladson-Billings, G. (2009). The dreamkeepers: Successful teachers of African American children. John Wiley \& Sons.

Laub, J. H., \& Sampson, R. J. (1995). The long-term effect of punitive discipline. In Revised from a paper presented at the Life History Research Society Meeting, May 1992. Cambridge University Press. http://dx.doi.org/10.1017/CBO9780511527906.015.

Moll, L. C. (1992). Bilingual classroom studies and community analysis: Some recent trends. Educational researcher, 21(2), 20-24. http://dx.doi.org/10.3102/0013189X021002020.

Perez, B. (2004). Language, literacy and biliteracy. In B. Perez (Ed.), Sociocultural contexts of language and literacy (pp. 25-56). Mahwah, NJ: Lawrence Erlbaum Associates.

Rogoff, B. (2003). The cultural nature of human development. Oxford University Press.

Valdés, G. (2001). Learning and Not Learning English: Latino Students in American Schools. Multicultural Education Series. Teachers College Press, 1234 Amsterdam Avenue, New York, NY 10027 (23.95).

Vygotsky, L. S. (1980). Mind in society: The development of higher psychological processes. Harvard university press.

Wood, D., Bruner, J. S., \& Ross, G. (1976). The role of tutoring in problem solving. Journal of child psychology and psychiatry, 17(2), 89-100.

\section{$($ cc) EY}

This work is licensed under a Creative Commons Attribution 3.0 License. 